\title{
The Influence of Training, Work Experience, and Competence on Employee Performance at Surabaya Husada Utama Hospital
}

\author{
Hyrnanda Era Dewanti ${ }^{1}$, I Putu Artaya, SE,MM² \\ Narotama University \\ ${ }^{1}$ hyrnandaera@gmail.com
}

\begin{abstract}
The purpose of this research are for known as training, work experience, and competence towards improving employee performance in Surabaya Rs Husada Utama. This research is a quantitave. The population and samples are based upon questionnaire that had been given to 56 respondesnts of Rs Husada Utama nurse in Surabaya. Data retrieval techniques by interview, observation and questionnaire. Data analysis that had been use are validity test, reability test, classic assumption test, and multiple linier analysis test. The research shows that the influence of training, work experience, and competence on employee performance Surabaya Husada Utama Hospital showed a positive and significant known amounted to $94.1 \%$. partially training has amounted to $17.7 \%$ influence on the performance of employes, work experience has amounted to $51.1 \%$ influence on the performance of employes, and the competence affects employee performance Surabaya Husada Utama Hospital amounted to $-11.5 \%$.
\end{abstract}

Keywords : Training, Work Experience, Competence, Employee Performance

\section{INTRODUCTION}

Human Resources is an important aspect of a company that needs to be explored and built so that humans can gain superior skills. Thus the completion of the tasks and responsibilities charged to him can be carried out properly. Well-managed hospitals and supported by human resources and adequate health equipment, the goal of the hospital is achieved, namely to be the people's choice in examining their health.

Efforts to maximize the quality of human resources can be started from the selection of a potential workforce with the appropriate level of education in work. Through adequate work experience employees have the competency to compete, especially in global competition and increasingly diverse consumer demands. There are many ways to improve Employee Performance at Husada Utama Hospital, such as through good service, optimal work experience, and work competencies that must be considered, if a hospital has and creates good work services can improve employee performance in handling and serving patient of Husada Utama Hospital.

As quoted on the report page lapor.go.id, which stated that there was a complaint from one of the Surabaya community that they mentioned complaints about the attitude of doctors at the Husada Utama Hospital, which essentially patients received treatment that was not in accordance with the standardization of international hospital services. The news can be quoted at (https://www.lapor.go.id/pengaduan/1740365/keluhan-tikap-dokter-di-rumah-sakit.html, accessed December 7, 2018, 18:30 WIB). Through observations seen at the level of Service and Handling need to be repaired and addressed. One of the factors needed by hospitals to participate in the competition and provide the best service for patients is Employee Performance.

The purpose of this research are for known as training, work experience, and competence on employee performance in Surabaya Husada Utama Surabaya parcial and simultaneously. 


\section{THEORITICAL FRAMEWORK}

\section{Human Resource Management}

(Newman dan Hodgetts 1998:4) "Human Resource Management is a process carried out by an organization or company to provide human resources that are used effectively in an effort to achieve the goals of the organization or company in accordance with individual goals."

\section{Training}

(Simamora, 2004:344) employee training or training is a systematic effort of the company to improve all the knowledge, skills and attitudes of employees through the learning process in order to be optimal in carrying out functions and tasks his position.

\section{Work Experience}

(Ranupandojo, 2002:18), said that work experience is an old measure or period of work that has been completed. One can complete work tasks and have been done well.

\section{Competence}

(Liestyodono dan Purwaningdyah, 2008) competence is knowledge, skills, and abilities that are mastered by someone who has become a part of him, so that he can perform cognitive, affective, and psychomotor behaviors as well as possible.

\section{Employee Performance}

(Mangkunegara (2005: 6)), states that the performance of Human Resources is a term of the word Job performance or Actual performance (work performance) is the work of quality and quantity that is achieved by an employee / employee in carrying out their duties in accordance with responsibility given to him.

\section{Previous Reseacrh}

(Leonardo William, 2015) training has a positive and significant influence on employee performance. Training is the lowest variable compared to the increase in company performance in this study. (Trisofia Junita Mamangkey, 2015) meaningless work experience on employee performance at PT Bangun Wenang Bevereges. (Ilman Ataunurl Eny Ariyanto, 2015) has positive and significant competence and training on the performance of PT Adaro Energy Tbk. The results of the first hypothesis verification are competencies that have a significant positive effect on performance.

\section{RESEARCH METHOD}

\section{Type of Research}

The research used in this study is quantitative, the process starts from theory, followed by using research and collecting research hypotheses collected from data collection / data collection and analysis, so that it can be obtained as research findings.

\section{Place and Time of Research}

This research was conducted at the Husada Utama Hospital Surabaya with the address Jl. Prof. Moestopo No.31-35, Surabaya. The time of the study was carried out from September to January 2019. 


\section{Conceptual Framework}

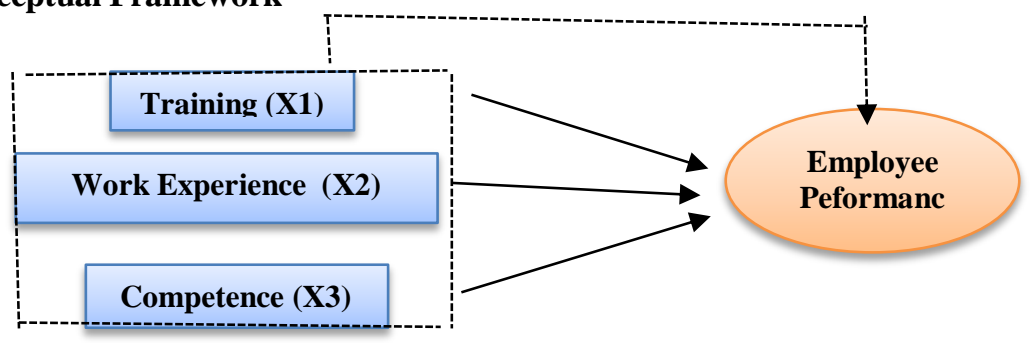

Sumber : Diolah Sendiri, 2019

\section{Population and Sample}

The population is a combination of all elements in the form of events, things or people who have similar characteristics that are the center of attention of a researcher because it is seen as a study (Ferdinand, 2006). This research is an employee of Husada Utama Hospital, Surabaya. The population in this study were all nurses who worked at Surabaya Husada Utama Hospital, amounting to 56 people. if the population is greater than 100 people, it can be taken $10-15 \%$ or $20-25 \%$ of the population. The sample is part of the number and characteristics possessed by the population (Sugiyono, 2008:81).

\section{Data Collection Method}

Primary data is original data collected by researchers to answer the research problem specifically (Riduwan, 2005b). Primary data in this study was obtained through the results of the questionnaire. The primary data needed in this study is regarding the training and performance of employees of Surabaya Husada Utama Hospital.

\section{Operational Definition of Research Variable}

X1: Training (X1) is (Andrew E. Sikula, 2011:117) states that training is a short-term educational process that uses systematic and organized procedures in which non-managerial employees learn knowledge and technical skills in limited objectives. (Garry Dessler dalam Suwatno, 2011:118) states job training is a process of teaching new or existing employees, the basic skills they need to carry out their jobs.

$\mathrm{X} 2$ : Work Experience (X2) is the process of forming knowledge or skills about the method of a job because of the involvement of these employees in the implementation of work tasks (Manulang, 1984).

$\mathrm{X} 3$ : Competence (X3) is an ability to carry out or do a job or task based on skills and knowledge and is supported by the work attitude demanded by the job (Wibowo, 2010).

Y: Employee performance (Y) is (Hasibuan, 2001:34) suggests "performance (work performance) is a result of work achieved by someone in carrying out the tasks assigned to him based on skills, experience and sincerity and time".

\section{Data Analysis}

\section{Method Reliability and Validity Test}

To test the validity of the measuring instrument, using the Pearson Product Moment formula contained in the SPSS data processor. If the instrument is valid, then the criteria used or the minimum limit for an instrument / questionnaire or test material are declared valid or considered to meet the requirements, if the value of the coefficient is $>0.300$ (Riduwan, 2005)While reliability intended to measure a questionnaire which is an indicator of a variable. Reliability is measured by the cronbach's alpha $(\alpha)$ statistical test. A variable is said to be reliable if it gives a cronbach 'alpha value $>0.60$ (Imam Ghozali, 2007:41).

\section{Multiple Regression Analysis Model}

(Kerlinger dan Pedhazur, 2004:18) The general equation of a simple linear regression line formula is as follows: Whereas to test regression linearity (significant or not regression), Fcalculate is used as the tester. Multiple linear regression models used:

$\mathrm{Y}=\mathrm{a}+\mathrm{b} 1 \mathrm{X} 1+\mathrm{b} 2 \mathrm{X} 2+\mathrm{b} 3 \mathrm{X} 3+\mathrm{e}$

Where :

Y: employee performance level score

A: constants 
b1, b2, b3: coefficient correlation

$\mathrm{X} 1$ : work facility variable dimension score

$\mathrm{X} 2$ : variable dimension score award

$\mathrm{X} 3$ : work environment variable dimension score

$\mathrm{E}$ : error estimet

\section{FINDING AND ANALYSIS}

\section{Realibility and Validity}

The value of Cronbach alpha for all variables greater than 0.6 is known. From the provisions that have been agreed before, all variables used for research are reliable. it can be seen that the value of sig. $r$ indicator question is smaller than $0.05(\alpha=0.05)$ or calculated $r$ value is greater than $r$ table $(0.245)$ which means that each indicator is valid, so it can be concluded as an independent variable (Training, Work Experience, and Competence) with the dependent variable (employee performance) can be used to measure research variables.

\section{Multiple Linier Regression Result}

Table 1 Multiple Linier Regression Result

\begin{tabular}{|c|c|c|c|c|c|c|c|c|}
\hline \multicolumn{9}{|c|}{ Coefficients } \\
\hline & & \multicolumn{2}{|c|}{$\begin{array}{c}\text { Unstandardized } \\
\text { Coefficients }\end{array}$} & \multirow{2}{*}{\begin{tabular}{|c|}
$\begin{array}{c}\text { Standardize } \\
d \\
\text { Coefficients }\end{array}$ \\
Beta \\
\end{tabular}} & \multirow[b]{2}{*}{$t$} & \multirow[b]{2}{*}{ Sig. } & \multicolumn{2}{|c|}{ Collinearity Statistics } \\
\hline \multicolumn{2}{|c|}{ Mode1 } & B & Std. Error & & & & Tolerance & VIF \\
\hline \multirow[t]{4}{*}{1} & (Constant) & .691 & .431 & & 1.604 & .115 & & \\
\hline & Belatihan & .851 & .048 & 1.213 & 17.703 & .000 & .240 & 4.160 \\
\hline & Rengalaman_Kexia & .406 & .079 & .394 & 5.112 & .000 & .190 & 5.256 \\
\hline & Kompetensi & -.513 & .044 & -.807 & $|-11.590|$ & .000 & .233 & 4.297 \\
\hline
\end{tabular}

Source: SPSS Output, 2019

Regression equation models that can be written from these results in the form of standardized regression equations are as follows:

$\mathrm{Y}=\mathrm{a}+\mathrm{bX} 1+\mathrm{bX} 2+\mathrm{bX} 3+\mathrm{e}$

$\mathrm{Y}=1,604+(17.703 \mathrm{X} 1+5.112 \mathrm{X} 2+-11,590 \mathrm{X} 3+\mathrm{e}$

From the above equation means:

a. The constant $(\alpha)$ is 1,604 , this shows that if there is no influence of the independent variable $(\mathrm{X} 1, \mathrm{X} 2$,

$\mathrm{X} 3)$ in the form of Training, Work Experience and Competence variables, then the employee's performance will remain at 1,604 .

b. Training regression coefficient (b1) has a negative value of 17.703 , this means that if the training increases by one unit it will increase the performance by 17,703 units.

c. Regression coefficient Work Experience (b2) has a positive value of 5.112, this means that if the Work Experience increases by one unit it will increase the performance by 5,112 units.

d. The Competence regression coefficient (b3) has a positive value of $-11,590$, this means that if Competency increases by one unit it will increase the performance by $-11,590$ units.

\section{Result of $\mathbf{R}$ and $\mathbf{R}^{2}$}

Table 2 Result of $\mathbf{R}$ and $\mathbf{R} 2$

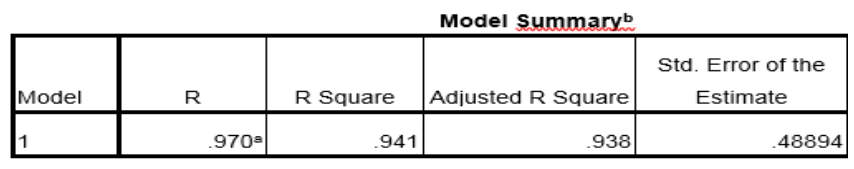

a. Predictors: (Constant), Kompetensi, Relatihan. Rengalaman_Keria

b. Dependent Variable: Kineria Karyawan

Source: SPSS Output, 2019

The value of R Square is 0.941 , it means that all independent variables: Training, Work Experience and Competence have positive relationship with Employee Performance. 
E-ISSN: 2656-1174 
Test of Classical Assumption Multicollinearity Result

Table 3 Multicollinearity Result

Coefficientsa

\begin{tabular}{|c|c|c|c|c|c|c|c|c|}
\hline \multirow{2}{*}{\multicolumn{2}{|c|}{ Mode1 }} & \multicolumn{2}{|c|}{$\begin{array}{c}\text { Unstandardized } \\
\text { Coefficients }\end{array}$} & \multirow{2}{*}{\begin{tabular}{|c|}
$\begin{array}{c}\text { Standardize } \\
\mathrm{d} \\
\text { Coefficients }\end{array}$ \\
Beta \\
\end{tabular}} & \multirow[b]{2}{*}{$\mathrm{t}$} & \multirow[b]{2}{*}{ Sig. } & \multicolumn{2}{|c|}{ Collinearitv Statistics } \\
\hline & & $\mathrm{B}$ & Std. Error & & & & Tolerance & VIF \\
\hline 1 & (Constant) & .691 & .431 & & 1.604 & .115 & & \\
\hline & Belatihan & .851 & .048 & 1.213 & 17.703 & .000 & .240 & 4.160 \\
\hline & Pengalaman. Kexia & .406 & .079 & .394 & 5.112 & .000 & .190 & 5.256 \\
\hline & Kompetensi & -.513 & .044 & -.807 & $|-11.590|$ & .000 & .233 & 4.297 \\
\hline
\end{tabular}

Source : SPSS Output, 2019

It can be explained that the questionnaire research data used can be used for further testing because of the results of this multicollinearity test, the research data has a VIF value of $<10$ and a tolerance value of less than 1.

\section{Heteroscedasticity Result}

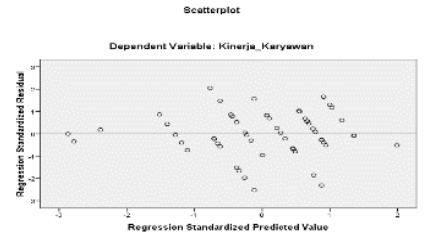

Figure 1 Heteroscedasticity Result

Source : Data Processed, 2019

Based on the results of heteroscedasticity test, it can be seen that there are no clear patterns and points spread above and below zero inj the Y. namely Training, Work Experience, and Competence.

\section{Normality}

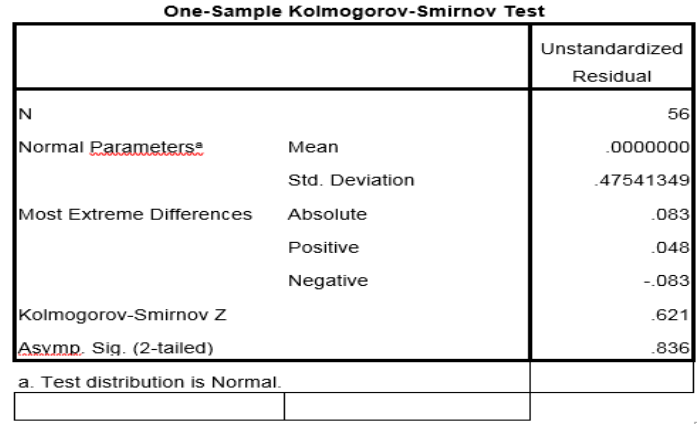

Figure 2 Normality Test Result

Source : Data Processed, 2019

In the table the results of testing the normal distribution with the Kolmogorov Smimov method to strengthen the testing with graphs obtained a significance value of $0.836>0.05$, so that the regression model is normally distributed.

\section{Hypothesis Testing \\ F-Test}

Table 4 F-Test Result

\begin{tabular}{|c|c|c|c|c|c|c|}
\hline & & $\begin{array}{l}\text { Sum of } \\
\text { Squares }\end{array}$ & df & \begin{tabular}{|l} 
Mean \\
Square
\end{tabular} & F & Sig. \\
\hline \multirow[t]{3}{*}{1} & Regression & 199.498 & 3 & 66.499 & 278.172 & $.000^{\mathrm{a}}$ \\
\hline & Residual & 12.431 & 52 & .239 & & \\
\hline & Total & 211.929 & 55 & & & \\
\hline
\end{tabular}


Source: SPSS Output, 2019

F-test is used to determine the whole effect of all independent variables to dependent variable. This test is done by comparing the value of Fcount with value of Ftable at $\alpha=0.05$. The overall influence of Training (X1), Work Experience (X2), Competence (X3) toward employee performance (Y) is very significant.

T-Test

Table 5 T-Test Result

Coefficients:

\begin{tabular}{|c|c|c|c|c|c|c|c|c|}
\hline & & \multicolumn{2}{|c|}{$\begin{array}{l}\text { Unstandardized } \\
\text { Coefficients }\end{array}$} & \multirow{2}{*}{\begin{tabular}{|c|}
$\begin{array}{c}\text { Standardize } \\
\mathrm{d} \\
\text { Coefficients }\end{array}$ \\
Beta \\
\end{tabular}} & \multirow[b]{2}{*}{$\mathrm{t}$} & \multirow[b]{2}{*}{ Sig. } & \multicolumn{2}{|c|}{ Collinearity Statistics } \\
\hline \multicolumn{2}{|c|}{ Mode1 } & B & Std. Error & & & & Tolerance & VIF \\
\hline \multirow[t]{4}{*}{1} & (Constant) & .691 & .431 & & 1.604 & .115 & & \\
\hline & Pelatihan & .851 & .048 & 1.213 & 17.703 & .000 & .240 & 4.160 \\
\hline & Pengalaman Keria & .406 & .079 & .394 & 5.112 & .000 & .190 & 5.256 \\
\hline & Kompetensi & -.513 & .044 & -.807 & -11.590 & .000 & .233 & 4.297 \\
\hline
\end{tabular}

Source: SPSS Output, 2019

1. Tabel 5 the results of the $t$ test for variable $X 1$ (Training) obtained a value of $t$ arithmetic $=17.703$ with a significance level of 0.05 . By using a significance limit of $0.05, \mathrm{t}$ table is equal to 2.262 . This means that $\mathrm{t}$ count $>\mathrm{t}$ table, which means Ho is rejected and $\mathrm{Ha}$ is accepted. Thus, the first hypothesis can be accepted. The direction of the positive regression coefficient means that training has a significant positive effect on employee performance. In other words, it can be concluded that training that is increasingly effective will improve employee performance.

2. Tabel 5 the results of t test variable $\mathrm{X} 2$ (Work Experience) obtained the value of $\mathrm{t}$ arithmetic $=5.112$ with a significance level of 0.05 . obtained $t$ table of 2.262 This means $t$ count $>t$ table, which means Ho is rejected and $\mathrm{Ha}$ is accepted. Thus, the second hypothesis can be accepted. The direction of the positive regression coefficient means that Work Experience has a significant positive influence on employee performance. In other words, it can be concluded that Work Experience that has more potential will improve employee performance.

3. Tabel 5 the results of $t$ test $X 3$ variable (Competence) obtained the value of $t$ count $=-11.590$ with a significance level of 0.05 . By using a 0.05 significance limit, $t$ table is obtained at 2.262 . This means $t$ count < table, which means Ho is rejected. Thus the third hypothesis is rejected. The direction of the negative regression coefficient means that Competence does not have a significant positive effect on employee performance. In other words it cannot be concluded that the more optimal Competence will increase employee performance.

\section{DISCUSSION}

The fourth hypothesis states that Training, Work Experience, Competence have a significant effect on performance. This is evident from the results of the questionnaire, the respondents stated that the company has provided Training, Work Experience and an Competence for them.

\section{Training on Employee Performance}

The first hypothesis proposed states that training has a significant effect on employee performance, partially this has been proven by the results of the t test value 17.703. This is rational because it is in accordance with the responses of respondents regarding Training. In response, respondents stated that the training provided by the company was in accordance with their expectations.

The fact is there is a significant influence Training on performance can be clarified by the results of multiple linear regression analysis. Multiple linear regression analysis also indicates that every increase in one training unit performance will also increase by 1,213. Means that the higher / greater the training, the better / higher the employee's performance.

\section{Work Experience on Employee Performance}

The second hypothesis proposed states that Work Experience has a significant effect on performance, partially this has been proven by the results of $t$ test value 5.112. In response, respondents stated that the Work Experience given by the company was in line with their expectations. 
The fact that there is a significant influence of Work Experience on performance can be clarified by the results of multiple linear regression analysis. Multiple linear regression analysis also indicates that every increase in one unit of Work Experience will increase performance by 0.394. Means the higher / greater Work Experience, the better / higher employee performance.

\section{Competence on Employee Performance}

The third hypothesis proposed states that Competence does not significantly influence performance, partially this has been proven by the results of t-test value of -11.590 . This is rational because it is in accordance with the respondent's responses regarding work skills. In response, respondents stated that the competencies given by the company were not in line with their expectations.

The fact there is no significant influence Competence on performance is made clear by the results of multiple linear regression analysis. Multiple linear regression analysis also indicates that every increase in one Competency unit the performance will also increase by -0.807 . Means that the higher / greater the competency, the better / higher the employee's performance.

\section{CONCLUSION AND RECOMMENDATION}

\subsection{Conclusion}

Based on the results of the research and analysis that has been done can be raised several things which are the conclusions of this study, namely:

1. Training has a positive and significant effect on employee performance, this means that if training increases it will improve employee performance.

2. Work Experience has a positive and significant effect on employee performance, this means that Work Experience increases, it will improve employee performance.

3. Competence does not have a positive and significant effect on employee performance, this means that competencies need to be improved in order to improve employee performance.

4. Together the three independent variables consisting of Training (X1), Work Experience (X2), and Competence (X3) one of them Competency (X3) is not significant, while the two independent variables are Training (X1) and Work Experience ( X2) has a positive and significant influence on Employee Performance (Y). This means that if Training and Work Experience increase together, it will improve employee performance.

\subsection{Recommendation}

Based on the results of the research and conclusions above, the researcher needs to provide suggestions as follows:

a. Training proved to have an effect on employee performance, so the company should pay attention to the provision of more effective training for employees according to their workload so that the overall performance of company employees can continue to increase and can achieve various objectives set by the company.

b. Companies should pay close attention to Work Experience for employees. This is so that companies get a good impact on employee performance.

c. The company should also improve employee competency by conducting education and training in order to improve employee knowledge and skills in the future.

\section{REFERENCES}

Ferdinand. (2006). PENGARUH KOMPETENSI DAN DISIPLIN KERJA TERHADAP KINERJA PEGAWAI PADA DINAS PERIZINAN KOTA YOGYAKARTA SKRIPSI.

Garry Dessler dalam Suwatno. (2011). the Effect of Training and Work Motivation on Employee Performance At Pt ., 118.

Hasibuan. (2001). Pengaruh kepuasan kerja karyawan terhadap kinerja karyawan pada CV Alam Prima Komputer Bandar Lampung, 34.

Ilman Ataunurl Eny Ariyanto. (2015). Pengaruh kompetensi dan pelatihan terhadap kinerja karyawan PT 
Adaro Energy TBK.

Imam Ghozali. (2007). PENGARUH MOTIVASI TERHADAP PRODUKTIVITAS KERJA

KARYAWAN PADA PT. TELKOM INDONESIA, Tbk CABANG MAKASSAR IBRIATI, 41.

Kerlinger dan Pedhazur. (2004). Pengaruh pengalaman kerja terhadap kinerja pegawai di Kantor Kecamatan Laham Kabupaten Mahakam Ulu, 18.

Leonardo William. (2015). Pengaruh pelatihan, penempatan kerja, dan kompensasi terhadap kinerja karyawan pada pt. bank sulutgo kantor pusat manado.

Liestyodono dan Purwaningdyah. (2008). Pengaruh Kompetensi dan Disiplin Kerja terhadap kinerja Pegawai pada Dinas Perizinan Kota Yogyakarta.

Manulang. (1984). Pengaruh Pengalaman Kerja dan Disiplin Kerja terhadap Produktivitas Kerja Karyawan Perusahaan Speaker Aktif Arofah Elektronik di Desa Gribig Kecamatan Kudus, 15.

Riduwan. (2005a). PENGARUH INSENTIF DAN PENGALAMAN KERJA TERHADAP KINERJA KARYAWAN DEALER BANYUWANGI MOTOR GENTENG.

Riduwan. (2005b). PENGARUH PELATIHAN TERHADAP KINERJA KARYAWAN PADA PT. HD FINANCE PALEMBANG.

Simamora. (2004). Pengaruh pelatihan dan motivasi terhadap kinerja karyawan studi kasus pada karyawan kampoeng Djowo Sekatul, Kendal, Jawa Tengah, 344.

Sugiyono. (2008). Pengaruh Pelatihan dan Pengembangan Karir terhadap Kinerja Karyawan PTBank Mandiri ( Persero ) Tbk Cabang Imam Bonjol Medan, 81.

Trisofia Junita Mamangkey. (2015). PENGARUH PELATIHAN, PENGALAMAN DAN LINGKUNGAN KERJA TERHADAP KINERJA KARYAWAN PADA PT. BANGUN WENANG BEVERAGES COMPANY MANADO.

Wibowo. (2010). Pengaruh Kompetensi Dan Pelatihan Terhadap Kinerja Karyawan Pt Adaro Energy Tbk. Telaah Bisnis. 